HB31

.M415

no. 540 


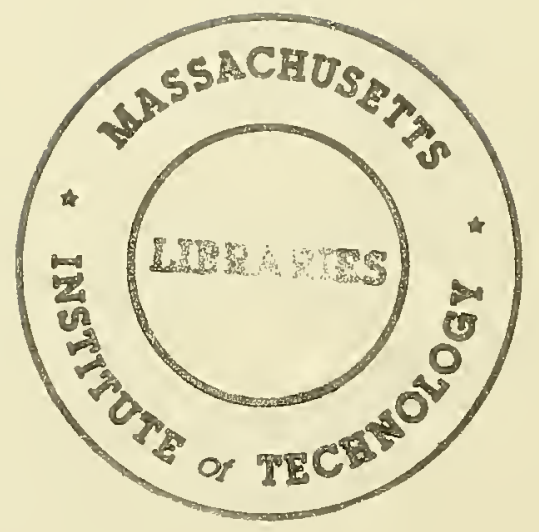





\section{Digitized by the Internet Archive in 2011 with funding from Boston Library Consortium Member Libraries}




\section{working paper} department

\section{of economics}

\section{EPISODES IN THE PUBLIC DEBT HISTORY OF THE UNITED STATES}

E. Cary Brown

No. 540

October 1989

\section{massachusetts institute of technology}

50 memorial drive combridge, mass. 02139 



\section{EPISODES IN THE PUBLIC DEBT HISTORY OF THE UNITED STATES}

E. Cary Brown

No. 540

October 1989 


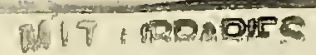

DEC \& 11989

RECEMVU 


\title{
EPISODES IN THE PUBLIC DEBT HISTORY OF THE UNITED STATES*
}

\author{
E. Cary Brown
}

October 1989

\begin{abstract}
Prior to the Great Depression of the 1930's, debt of the United States government was created in connection with wars and substantially liquidated postwar through budget surpluses from tight fiscal policies. These tight fiscal policies, dominant in the 19 th century, developed from a revenue system solely dependent on custom duties into a protective system that yielded far more income than was necessary for the limited role accepted by the 19 th century federal government. Moreover, these war debts were generally repaid at lower prices than when accumulated, in marked contrast to the later debt accumulations. thus increasing the amount of real debt was owed.

This paper reviews these periods of debt accumulation and repayment, separating the changes in the debt into those resulting from repayment (or accumulation) and those resulting from price changes. In the 19th century, and especially after the Civil War, the falling price level sharply increased the burden of the debt without a corresponding adjustment of interest rates. The opposite is nearer the truth initially after World War II, and surely from 1974 to the present.

Debt/GNP ratios in the United States have never been extremely hith for long periods of time. After the Civil War, this ratio rose to nearly 50 percent, by far its highest figure up to that time, and unapproached in World War I. The highest ratio, reached at the end of World War II, was rapidly reduced from 114 percent by inflation and growth to a postwir low of 23 percent in 1974, and has risen since to more than 40 percest.
\end{abstract}

* Prepared for the Conftrence on Capital Markets and Debt Management of the Italian Macroeconomic Policy Group and the Centre for Economic Policy Research. Castelgundolfo, Italy. June 15-17, 1989. 

EPISODES IN THE PUBLIC DEBT HISTORY OF THE UNITED STATES

\section{Introduction}

The United States has undergone four major periods of debt reduction over its history: the Revolutionary War and War of 1812 debt repayment extended over the first third of the 19th century; the Civil War debt was reduced in the last third of that century; and the debt repayment of World Wars I and II covered the third decade and third quarter of the 20th century, respectively.

Until the time of the Great Depression of the 1930s, the major reason for borrowing by the United States government was the preparation for or waging of war. Until then a relatively narrow stance had been maintained with respect to the kinds of programs considered appropriate to undertake. State governments, on the oiher hand, had assumed a broader role in the 19th century in financing transportation and other developmental projects. Local governments grew explosively after the Civil War to provide needed urban utilities and infrastructures.

Up to World War II, the expected and well-accepted policy of the federal government was to repay outstanding debt in a more or less systematic way, even when accompanied, as it often was, by substantial subsidies to creditors through price deflation. It could be characterized as a creditor-dominated policy. In contrast, after World War II debt repayment was minimal, but inflation and economic expansions, even when slow, sharply lowered the debt to GNP ratio--a debtor-dominated policy.

In reviewing these episodes the debt/GNP ratio will be used, when feasible, as a simple measure of debt burden, although other factors are, of course, present. Changes in this ratio come about (1) because the real debt increases or decreases through borrowing or repaying, and through fluctuations in prices; and (2) because the real GNP expands or contracts. For the 18th and 19th 
Public Debt History - 2

centuries, consistent annual estimates of GNP are unavailable, and measurement of annual price changes requires the use of the wholesale price index of Warren and Pearson (1933) which probably exaggerates movements in the general price level. Only in the 20 th century are annual estimates of real and nominal GNP available. Tables 7 and 8 contain the annual data used, and Table 4 sums up changes in debt for particular periods when it expanded and contracted.

\section{Revolutionary and War of 1812 Debt: $1775-1835$}

The Revolutionary government, virtually unable to borrow until the victory at Saratoga in 1777, depended almost entirely on the issuance of paper currency as the only way it could secure resources. By the end of hostilities. however, it was on a specie basis and emerged with a debt of $\$ 36$ million. When the constitutional government was organized in 1789 , the debt had grown half again as much, as the government struggled with essentially insoluble fiscal problems and met only one-fourth of its debt service. The first major legislative action of the new government was to provide a revenue structure that relied almost exclusively on customs duties, a choice that was to plague the young nation in a variety of ways for at least a century, supplemented by modest amounts from the sale of public lands from the huge public domain. A highly legislative enactment further increased the debt in 1790 to $\$ 76$ million when the states' war debts were assumed. The total debt at that time was perhaps 20-30 percent of GNP.'

Activist in strengthening the national government, the twelve-year Federalist administration, 1789-1800, enlarged the tax structure. Consequently, the debt grew only 10 percent in nominal terms (after the assumption of state debts) and decreased almost one-fourth in real terms. Despite real net borrowing of 9 percent, price inflation had reduced the debt by 32 percent (Table 4).

When Jefferson's administration replaced the Federalist in 1801, it initiated a decade of fiscal restraint: expenditures were reduced, especially military, from 
the high levels of Adam's administration; internal taxes were eliminated; a booming foreign trade doubled customs duties; and large budget surpluses were applied to debt reduction (Table 5). Up to the eve of the War of 1812, both the nominal and real debt were reduced by 45 percent entirely attributable to explicit debt retirement (Table 4). The debt had fallen to 6-8 percent of GNP through a fiscal policy that cut both taxes and expenditures.

The War of 1812 tripled expenditures, increased internal revenues by much less and with a lag, through reenactment of the direct property tax and the Federalist excises, while customs revenues dropped substantially although rates were doubled. The nominal debt had increased to a new peak of $\$ 127$ million; the real debt had more than doubled by the end of 1815--increased by net borrowing (140 percent), decreased by inflation (30 percent) (Table 4 ).

Deficits were quickly turned into surpluses as the United States was flooded by imports, especially from Britain. In the years 1816-19 more customs duties were collected than ever before, partly because of the doubling of rates, but also because of large pent up demands for British goods. Serious unemployment overtook the domestic industries that had gained a foothold during the wartime interruption of trade, and the crisis of 1818 developed into the depression of $1820-21$.

This depression and the repeal of wartime taxes eliminated these surpluses briefly. Recovery brought many years of budget surpluses that were heightened in the mid-1830s by heavy speculation in public lands. Revenues averaged 40 percent more than expenditures in the 20 years after the War of 1812 (Table 5), and the public debt was completely liquidated in 1834 from its high point in 1815. Since prices were falling in much of this period, the real value of debt repayments exceeded the initial real debt by 60 percent (Table 4). This redistribution from taxpayers to bondholders recurred even more dramatically after the Civil War. 
The elimination of a public debt by a central government is a rare happening in fiscal history. The maintenance of such large budget surpluses and their application to debt repayment demanded a disciplined approach on both the expenditure and the revenue side. The rigid control of expenditures exercised by the several administrations was extraordinary, especially after 1820 when internal improvements and the provision of enterprise capital became a growing need and a major policy issue for a developing nation. Various presidents, with the ineffective exception of John Quincy Adams, opposed the federal government's undertaking such programs, usually expressing the belief that the constitution prevented it. ${ }^{3}$

States on the other hand had no such constraints. Essentially debt free after the assumption of the states' war debts by the federal government in 1790 , state debt was only $\$ 13$ million by 1825 (Table 6). States were performing only a few elementary functions; their budgets were quite small; interest constituted 50 to 90 percent of their total expenditure, and raising taxes for interest payments was unpopular.' Faced by expanding capital demands and the spectacular success of the New York state-financed Erie Canal, ${ }^{5}$ state borrowing took off after 1830 most importantly to develop canals, railroads, and, after Jackson's 1832 veto of the bill rechartering the Second Bank of the United States, banks. By 1838 state debt of $\$ 174$ million exceeded federal debt. ${ }^{6}$

With such a clearly defined and implemented expenditure policy and without any debt, one could imagine the federal government eliminating its primary budget surplus and achieving fiscal bliss forever after: that is, cut the revenues to fit the expenditure program. However, once customs duties were made almost the sole revenue source, their protective usage became irresistible. From the initial debate over the modest rates proposed by Madison in 1789, protectionism moved swiftly forward: rates were doubled in the War of 1812; manufacturers were protected from postwar competition beginning with the act of 1816 , 
especially of products that had sprung up during the war such as cotton and woollen goods, iron, and glass; the tolerable political threshhold of the nonmanufacturing sections was even exceeded by unsustainably high rates in the 1828 Tariff of Abominations, which led some states to threaten nullification of the legislation that was then temporarily moderated in the early 1830 s.

A strong defensive argument for high customs duties had been their fruitful revenue yield that could retire the debt. But in the years 1834 and 1835 with no further debt to retire, protectionist supporters had to regroup and develop a new rationale. Political genius found a way. Tariff rates would not have to be reduced (or raised, as was attempted near the end of the century); more federal spending, clearly anathema to President Andrew Jackson, could be avoided; excess revenues would be given back to the states, and they could expand crucial programs foresworn by the federal government. ${ }^{7}$ Thus it was voted in 1836 to turn back to the states an estimated $\$ 36$ million in surplus revenues, more than half the revenues collected in that year. Because of its novelty and perhaps for constitutional reasons, the expenditure was labelled a loan, callable if needed, though it never was.

Before the final quarterly installment was paid, the panic of 1837 terminated this fiscal experiment. This panic also caught most states in the midst of internal-improvement programs with uncompleted canals and railroeds. As the severe deflation continued until $1843,^{\circ}$ it brought losses in market values and default on half of the outstanding state debt, 10 percent of which was repudiated. ${ }^{9} \quad$ Unsuccessful efforts were made to persuade the federal government to assume or support these debts, and many foreign lenders failed clearly to delineate the two levels of government. Thus, default and repudiation of state debt may have affected the otherwise impeccable credit standing of the federal government. ${ }^{10}$ The financial difficulties and mismanagement that were exposed led to the enactment of various types of constitutional debt limits in most states. 
By the time of the Civil War, the federal debt had grown to $\$ 65$ million after fluctuations resulting from the business cycle and the Mexican War, less than 2 percent of GNP (Table 6). State government debt, after shrinking in the 1840s, had a miniboom in the 1850 s as developmental programs were reactivated. In the latter decade local government debt rose five-fold to $\$ 200$ million and, though still smaller than state debt, surpassed the federal (Table 6). This expansion was mostly in city debt in which the rapid increases in population and income extended city programs and services, and some competition for railroad connections through offers of loans and subsidies. This substantial borrowing became a heavy burden in the 1857 depression and, again, defaults resulted." III. The Civil War Debt: 1860-93

\section{III.1 The War Period: 1860-65}

The Civil War resulted in an explosion in size of the public debt, an expansion of expenditures to 12 percent of GNP (compared with 4 percent in the War of 1812), ${ }^{12}$ innovations in taxation, both qualitative and quantitative, that substantially broadened tax sources and brought in large amounts of revenue; innovative marketing of the public debt; conscription of military personnel; and major changes in the banking system.

Congress took the lead in designing wartime fiscal policies, enacting the first federal income tax which reached a top rate of 10 percent, and an inheritance tax. The bulk of the revenue was provided by a massive array of excise taxes, both ad valorem and specific, that covered a large portion of market transactions, multiple taxes on manufactured products much like a turnover tax, stamp duties on a variety of transactions, and gross receipts taxes on such industries as railroads and utilities. These taxes required the creation of a whole new administrative apparatus--the Office of Internal Revenue in the Treasury-and were slow to reach their potential. Yet, revenues at their peak in fiscal year 1866 raised over half a billion dollars--almost 13-fold more than in 1861-- 
Public Debt History - 7

compared with peak expenditures of $\$ 1.3$ billion in fiscal year 1865 . The nominal public debt rose from $\$ 65$ million at the beginning of the war to $\$ 2.7$ billion at its end. By far the largest debt yet incurred, it resulted in the highest debt/GNP ratio, 41 to 49 percent, for the country up to that time. ${ }^{13}$

The Confederacy, on the other hand, could not develop an effective tax program given the structure of its economy and the need for creation of a central government from scratch. During the war only about 10 percent of the government's expenditures were covered by taxes, $\$ 2$ billion were borrowed, almost as much as the North but mostly in the form of paper money, and repudiated after surrender.

\section{III.2 The Period of Debt Repayment: 1866-93}

In the immediate postwar years the federal government reviewed the tariff-tax structure to adjust it to long-term peacetime needs. The economic and political prostration of the South in the reconstruction and postreconstruction periods weakened the effective opposition to protectionism. Budget surpluses were crafted around protective customs duties that were increased substantially above their prewar level. In the decade of the 1850 s they averaged $\$ 50$ million; by the 1866-1875 period they jumped to an average of more than $\$ 200$ million. ${ }^{14}$ The ratio of duties to free and dutiable imports rose from a prewar low of 14 percent in 1861 to $41-46$ percent up to 1871 , then moved down to around 30 percent in the $1870 \mathrm{~s}$ and $1880 \mathrm{~s} .{ }^{15}$

The wartime tax structure was dismantled. Income and inheritance taxes, its progressive elements, were eliminated by 1872. Almost all the many excise, stamp, licensing, and other internal duties were swept away by 1874 with the major exception of liquor and tobacco taxes that provided more revenue at lower rates than they had during the war--30 percent of total 1874 revenues. Expenditures, though well above prewar, were cut back from their wartime levels. Thus, average nominal surpluses were expanded dramatically--from an average 
Public Debt History - 8

of $\$ 3.6$ million in the prewar decade to an average of $\$ 66$ million in the decade 1875-84 following repeal of wartime taxes. ${ }^{15}$

In the period following the Civil War to the depression years after 1893. the nation witnessed a remarkable series of economic developments: (1) real GNP growth averaged 5 percent per annum; ${ }^{17}$ (2) prices fell at an average rate of 2 or 3 percent per annum: $:^{18}$ (3) nominal yields on U.S. bonds slowly fell from over 6 percent in the late 1860 s to $2-2.5$ percent in the late 1880 s and early 1890 s; $^{19}$ and (4) budgets were in surplus almost continuously.

The ratio of real debt to real GNP fell sharply in the postwar period: from 39 percent in 1871 to 8 percent in 1891 (Table 1). The factors accounting for this change were: (1) the resumption of specie payments in 1879 eliminated the gold premium; (2) real debt repayment only reduced the real debt by 10 percent after adjusting the data in Tables 4 and 7 for the difference between Kuznets'

Table 1

Factors Reducing the Debt/GNP Ratio $1871-91$

Debt/GNP Ratio, 1871

$39 x$

Resumption of specie payment

$-4 x$

Real growth to 1891 (2.87 fold)

$-23$

Net real debt repayment

$-10 *$

Net price changes

$+6 *$

$-31$

Debt/GNP Ratio, 1891

8

*Adjusted for difference between price indices (see text).

implicit GNP price indices and the wholesale price indices of Warren and Pearson; 
(3) price decreases offset 60 percent of the net debt repayment, again after adjusting for the difference between the two price indices as in (2) above, and (4) real growth of 2.87 -fold clearly dominated all other factors. ${ }^{20}$

Real debt repayment exceeded the initial real value of the debt at the end of the Civil War, but the real debt only fell 15 percent (Table 4). Nominal interest rates could, of course, have adjusted--in this case to have decreased 2 or 3 percent--and thus maintained debtors and creditors in the same real positions as before the deflation. However, it took nominal interest rates several decades to fall that much. Real interest yields for the 10-year period 1869-78 were a high 10.3 per cent compared with the prewar decade of 2.6 percent. ${ }^{21}$

In such a world, one must indeed repay debt rapidly just to hold it constant, similar to Alice's frustrating excursions with the Red Queen. With real interest rates averaging more than the growth rate for much of this period, it was the hard way to grow out of debt. Nevertheless, economic growth at such a rapid rate came to dominate even the falling price level.

Redistribution via the fiscal structure is always a concern when taxes are used to repay debt. The post Civil-War structure must be described as regressive--very few benefits on the expenditure side for the lower income groups and a tax-tariff structure loaded heavily on consumers. The form of this structure was such that price deflation exacerbated it. While ad valorem taxes would not have been subject to this defect, specific commodity taxes, such as tobacco and liquor and many of the customs duties, increased in real terms when prices fell.

Nevertheless, despite a regressive internal-external excise-tax program that responded to falling prices with rising real tax rates, it should not be assumed that these taxes imposed a heavier burden on individual taxpayers. While prices were falling, real wages and income were increasing in the latter part of the 19 th century. ${ }^{22}$ The distributional question would have to be explored in detail to make a reasonably precise assessment of the impact of falling 
Public Debt History - 10

prices on taxes and incomes. This was a period of vibrant business expansion. of heary immigration, of high protectionism, of growth of large enterprise, of increasing business concentration, and of government corruption.

The distributional strategy of a tight fiscal policy financed by consumption taxes came under increasing political attack as the century waned. Opposition increased to what was seen as a deflationary redistribution of income from debtors to creditors, and a regressive fiscal structure harnessed to repay debt. As the political situation became increasingly unstable, protectionists tried to reduce the surplus by eliminating the excises on tobacco and liquor. They were unsuccessful because the public regarded them as good taxes. With more success, certain expenditure programs were expanded, particularly veterans pensions and public works, ${ }^{p 3}$ perhaps in a search for some offsets to the regressivity of the revenue side.

The Harrison administration in a last major attack on the surplus furthered the McKinley tariff of 1890 that raised tariff rates (in order to reduce tariff revenues by increased duties) and increased veterans' pensions. These tariff policies were reversed soon after the depression of 1893, and an income tax added after heavy pressures from the Populists and the West. The Supreme Court, however, declared it unconstitutional in a controversial decision before it could become operative. Budget surpluses finally came to an end following the panic of 1893 with the debt down to $\$ 1$ billion--8 percent of GNP. By 1900 the depression of the mid-1890s followed by the Spanish-American War increased the debt to $\$ 1.3$ billion.

The Victorian prose of Henry C. Adams richly sums up this episode. "The claim that is here urged in support of deficit financeering is especially pertinent when the machinery of taxation is used for other than revenue purposes, for, under such conditions, those interested in the maintenance of existing fiscal laws will show them- 
selves very ingenious in finding occasions for public expenditure. It is not too much to say that the Arrearage Pension Acts, by means of which the treasury was relieved of its plethora of funds, find their true explanation in the desire of Congress to maintain inviolate the system of protective duties. This could not be done in the face of an ever-increasing surplus, and protectionist politicians did not dare to advocate the abolition of the whiskey tax; it only remained for them to spend the money." ${ }^{44}$

He concluded:

"It is the policy of protection that has paid our debts. This was true in the period from 1816 to 1836 , and it is true at the present time [1887]. The wisdom of our statesmen consists in this, that they have not used unwisely the surplus revenue forced upon them by a radically pernicious system of taxation."2s

\section{3 The States}

The Civil War was to make a tangle of the debts of the Southern states. At the beginning of the war the bulk of Southern state debt was owned by the North, and, not surprisingly, interest was not paid on these bonds during the war. Almost no taxes were imposed by the Southern states at first, but they were turned to more and more as the war went along. After the war President Johnson emphatically directed the states to repudiate them after they had initially taken no action. The repudiation of these debts for all time was a bitter pill for them to swallow, particularly because the Southern banks were major holders of these debts and would be liquidated with the disappearance of such assets.

Reconstruction in the South presented a sorry picture of vindictiveness and venality in the supervision and rebuilding of an impoverished economy. Upon admission of the 11 states by 1870 , the control of the governments was in 
the hands of Congress. Shoddy financial practices permitted state debts to increase from $\$ 146$ million at the beginning of reconstruction in 1870 to $\$ 248$ million by the end of 1874 , about half of which was repudiated or scaled down in the depression of the 1870s.

The Northern states, on the other hand, steadily reduced their debt from 1870-90 largely through taxation and debt retirement. The total government debt to GNP ratio by 1900 was down to 15 percent--much lower than the 49 percent of 1870 , but higher than the 1860 ratio of 12 percent. The substantial increase of local debt--from $\$ 0.2$ to $\$ 1.6$ billion--is notable (Table 6). IV. World War I Debt

\section{IV.1 Federal Government Accumulation: 1917-19}

From the depression of the mid-1890s through the era of reform of the first Roosevelt and Woodrow Wilson up to 1916, the eve of entry of the United States into the war, the nominal debt had remained virtually unchanged at $\$ 1$ billion while the real debt diminished steadily as prices rose from their depression levels. The debt was a low 3 percent of GNP in that year.

War mobilization accelerated government expenditures in the three following years to a peak in 1919 of more than 20 percent of GNP. As in the Civil War, the wartime tax structure was innovative. A constitutional amendment explicitly permitting an income tax had received state ratification by 1913; its availability was quickly exploited and, from a modest beginning of 1 percent, the top bracket by 1919 reached nearly 80 percent. An excess-profits tax was enacted for the first time, and applied both to unincorporated firms as well as corporations in contrast with later practice. Perhaps the most intriguing fiscal novelty was the passage of a tax act in 1919 after the war had ended with major retroactive tax increases on 1918 incomes and profits.

Corporate and personal income taxes and the excess-profits tax provided the bulk of wartime revenues--a dramatically different distributional structure 
Public Debt History -13

from that of the 19 th century. This revenue effort developed more slowly than the expenditure side so that only 30 percent of spending was covered and the nominal debt grew to $\$ 25$ billion by 1919,30 percent of GNP.

IV.2 Repayment: $1920-30$

In the postwar period a return to what was to be called "normalcy" by President-elect Harding was broadly favored by the public. Expenditures were quickly reduced to their average for the coming decade, while revenues involved much more controversy and were lowered less rapidly. Moreover, the large 1919 deficit of $\$ 15$ billion, 18 percent of GNP, was replaced by a modest surplus in 1920--a large swing in fiscal policy. Output dropped sharply in 1920 and 1921; and in the latter year the inflation turned into a sharp deflation, increasing the real value of the debt, and raising the debt/GNP ratio to 34 percent.

Postwar tax reductions were applied first to the special wartime levies, like the excess-profits tax, and then to the high wartime rates on personal and corporate income. The permanent tax structure developed by the mid-1920s generally followed the views of Secretary of the Treasury Mellon that taxes on higher incomes should be cut sharply to provide incentives for saving and risk-

Table 2

Factors Reducing the Debt/GNP Ratio

1919-29

Debt/GNP Ratio, 1919

$30 \times$

Real growth to 1929 (1.34-fold)

$-8$

Net real debt repayment

$-8$

Net price changes

$+2$

$-14$

Debt/GNP Ratio, 1929 
taking. By 1926 the top income-tax bracket had been lowered to 25 percent.

The lag in tax cuts behind expenditure reductions produced surpluses in every year. Applied to debt repayment, they proved as important as the decade's income growth in reducing the debt/GNP ratio. The nominal debt was reduced by a third, or $\$ 9$ billion, and by 1929 it stood at its postwar low of 16 percent of GNP. This reduction was almost equally accounted for by debt repayment and output growth. Price deflation was a modest though present factor (Table 2).

\section{IV.3 State and Local Debt}

State and local debt was being added to throughout this decade in about the same amounts as federal debt was being retired. An expanding GNP brought the total debt/GNP ratio down from 44 percent in 1922 to 35 percent in 1927 . By 1932, however, the lowered income and increased depression borrowing pushed this ratio up to 66 percent (Table 6).

\section{World War II Debt Experience}

The World War II experience had many novel features: the magnitude of mobilization--at its peak half of GNP; falling yields on government securities as the war progressed; debt exceeding GNP by the end of the war; and the postwar reduction of a substantial fraction of the debt by inflation.

With such a huge build-up of expenditures, debt grew rapidly despite much innovation on the tax side: conversion of the personal income tax to a mass tax (a 10-fold increase in taxpayers), the initiation of withholding which made the tax a more effective stabilizing instrument, and an administration proposal for a progressive consumer-expenditure tax that Congress rejected. A major feature of the stabilization program was the distributional compromise that held together disparate groups in a kind of implicit social contract of fair shares: price controls, wage controls, excess-profits taxation, rationing and direct allocation of scarce materials, and low interest rates. 
Public Debt History -15

In the postwar period, President Truman followed tight fiscal policies that reduced the nominal debt. Prices rose sharply in 1946 and 1947 after premature elimination (by the standards of the administration) of price and other controls. From then on inflation became virtually the only factor reducing real debt: it took a major or equal postwar position with growth in reducing the debt/GNP ratio.

It surely was not the intention of the government to follow a policy of debt reduction through inflation, though it should not be forgotten that the administration's support of early elimination of the excess-profits tax in 1945 was probably decisive in breaking the deadlock between the House and the Senate on this issue. Elimination of this tax shattered the wartime stabilization compromise and doomed continuation of wartime price and wage controls. ${ }^{26}$ Nevertheless, President Trumun was to take many courageous positions in support of a tight fiscal stance: opposition to premature Congressional tax reductions in 1946 and 1947; support of prompt and high taxation in the Korean War that eliminated heavy pressures on direct controls. The Eisenhower administration surely would not have advocated inflationary policies to reduce debt, but by then the wartime debt/GNP ratio had been cut almost in half.

The relative weight of output growth, net real debt repayment, and inflationary changes in real debt are shown in Table 3 for three postwar periods beginning with 1945 and ending about a decade apart, the last of which ends with the lowest debt/GNP ratio of the postwar period, 1974. In the first decade, inflation overpowered growth and debt repayment in reducing the debt/GNP ratio; growth and inflation were almost equal in the two-decade postwar period; and in the three-decade period ending with the oil shock in 1974, growth forged ahead, but by then net borrowing had also begun to be a factor. Some inflation has ruled in every postwar year except 1949. 
Table 3

Factors Reducing the Debt/GNP Ratio

Debt/GNP Ratio, 1945

Terminal Year

Real growth to

Net real debt repayment to

Net price changes to

Total change

Debt/GNP Ratio, Terminal Years

\section{$110 x$}

$\underline{1955} \underline{1965} \underline{1974}$

$-10 \quad-39 \quad-55$

$-3+3+10$

$-42 \quad-38 \quad-41$

$-55 \quad-74 \quad-86$

$56 \% \quad 37 \% \quad 23 \%$

The federal share of total government debt has fallen in the postwar period as state and local governments returned to their normal activities suspended during the war. In 1950 the federal proportion was 76 percent; by 1980 it had reached 26 percent, but has subsequently risen. State and local debt in 1960-85 has kept pace with GNP in the 12 to 15 percent range (Table 6). VI. Observations and Conclusions

1. Fiscal policy of the United States in the 19 th century could not be described as one driven by an autonomous expenditure structure to which taxes were adjusted: on the contrary. The government began with custom duties as its major revenue source; it became gripped by protectionism and used tariffs to achieve that end. Revenue yields were generated well beyond the expenditure programs, barring wars, desired by the public. Protectionism thus dominated the generally tight fiscal policies of that century and budget surpluses, with a consequent rapid debt retirement, created political "problems."

2. While a government may become a captive of policies that generate more 
Public Debt History -18

5. There are some similarities between the present fiscal problems of the United States and the 19 th century experience. Like the 19th century revenue structure, the present one has been fixed by nonrevenue considerations: the desire to force down the size of government, rather than promoting protection. Unlike the 19th century structure, it fails to support the expenditure programs desired by the public. As a consequence we are confronted by chronic deficits instead of chronic surpluses. This unstable situation has raised the debt/GNP ratio to nearly double its level in 1974 , the lowest point in the postwar period.

E. Cary Brown Massachusetts Institute of Technology

\section{Notes}

1 Trescott (1960) 342 is the low figure; Barro (1984) 368, using unpublished data of Robert Gallman, is the high one.

I Trescott (1960) 360; Barro (1984) 368.

3 Madison near the end of his administration announced his support of internal improvements of national interest. John Quincy Adams had a full-scale program involving internal improvements, but Congress successfully thwarted it.

- Ratchford (1941) 46. This work is an indispensable source for state finances and has been relied on extensively in this paper.

5 The Erie Canal debt was repaid from the canal's revenues in 10 years. The cost of freight dropped dramatically--Buffalo to New York City from $\$ 100$ to $\$ 15$ per ton--ultimately diverting substantial amounts of traffic from the Ohio and Mississippi valleys to New York City. 
Public Debt History -17

revenue than is normally needed for financial reasons, budget surpluses will result only if expenditures are contained. The expenditure restraint shown in the first half of the 19 th century was remarkable. The dominant theme of limited government was anchored at one end by Jefferson and at the other, even in the face of growing needs for transportation development, by Jackson. State governments necessarily became involved in these programs with consequent reductions in efficiency.

Opposition grew to the distributional effects of these tight monetary and fiscal policies, both to the debtor-creditor redistribution and to the regressiveness of the revenue system. As political support weakened, the backers of high customs gave way on the expenditure side, offering pensions and public works; and they surely were surprised on the revenue side when they made an incometax concession in 1909 that became a constitutional amendment. The income tax changed substantially the impact of the fiscal program in the 20th century, and permitted the debt repayment of the 1920 s.

3. In the 19 th century the government usually borrowed when prices were high and repaid when they were low. Even after World War I, the sharp decline in prices in 1921 increased the real value of the debt, although the rest of the decade was one of price stability. Not until the first decade after World War II was real debt repayment accompanied by price changes that reduced. rather than increased, the real debt (Table 4).

4. The Civil War debt was doubled in real terms by falling prices; this price increment was slightly more than offset by substantial debt repayment; but the growth rate was so substantial that it dominated both factors in reducing the debt/GNP ratio. World War I debt reduction came through almost equal parts of repayment and growth. In contrast, World War II's came through inflation and growth, in about equal proportions over 20 postwar years--inflation dominated in the first decade, growth caught up in the second. 
Public Debt History - 19

- Classified by purpose of borrowing, banking accounted for \$54 million, canals $\$ 60$ million, railroads $\$ 43$ million, turnpikes $\$ 7$ million and $\$ 9$ million was of a miscellaneous character. Transportation accounted for almost two-thirds. Ratchford (1941) 87.

Trescott (1955) 140 estimates that most of this distribution promoted capital formation either directly or indirectly, although many of the investments were of doubtful merit.

- Temin (1969) 155-165.

- Hempel (1971) 16-18, 32. Of $\$ 245$ million outstanding in the period 1837-1843, $\$ 125$ million was in default, and $\$ 14$ million was repudiated.

10 European lenders were ready purchasers of many of the states' debts, but were understandably put off by the defaults and, later, repudiations. Secretary of the Treasury Bibb in his Annual Report for 1844 stated: "If aliens, not understanding the texture of the National Government, do not distinguish accurately between engagements entered into by the Government of the United States, and those entered into by the several States... have distrusted the credit of the National Government .... such distrust is to be regretted." Quoted in Childs (1947) 29.

11 Studenski and Krooss (1952) 133-136.

17 Trescott (1957) 62.

13 The government had suspended specie payment in 1862 , except for customs duties and "virtually all interest and principal payments on its debt," not to be resumed until January 1, 1879. Friedman and Schwartz (1963) 27. The debt service, therefore, required premium payments in currency, and the debt should 
Public Debt History - 20

logically be valued at the currency price of gold in this period. Trescott (1966) made such adjustments to budget data for 1862-75, and they are incorporated in Table 5. This premium was highest in 1864 and would have doubled the size of the debt in currency prices. The $\$ 2.7$ billion debt at the end of the war shown in Table 7 would be increased to $\$ 3.8$ billion in currency prices. For the gold value of currency, see Warren and Pearson (1933) 351.

The implicit nominal GNP in 1865 of $\$ 9.2$ billion, in Barro (1984) 368, when applied to the debt figure adjusted for the gold premium, yields a ratio of 41 percent. The higher figure is that obtained from Kuznets' estimate of average nominal GNP for 1869-73 of $\$ 6.7$ billion increased by 15 percent--the proportion implicit in Barro's data. This $\$ 7.7$ billion GNP yields the 49 -percent ratio in the text. For Kuznets' estimates, see Historical Statistics (1957) Series F3.

14 Table 5 for the 1850s; Trescott (1966) for the later decade.

15 Historical Statistics (1957) Series U19.

16 Studenski and Krooss (1952) 163.

17 Kuznets' real GNP measured from the mid-points of his 5-year averages, 1871-91. Historical Statistics (1957) Series F3.

1. The Warren and Pearson (1933) wholesale price index fell 2.9 percent per year from 1866-93; 2.2 percent per year from 1871-91. From the mid-points of Kuznets' 5-year GNP averages the implicit GNP deflator fell 1.9 percent per year from 1871-1891. Historical Statistics (1957) Series F5.

19 Sylla (1975) 287 has computed U. S. bond yields for the period from 1869 to 1892 that shows a steady decline from 6.87 percent to a low of 2.11 percent in 1889 ending with 2.69 percent. 
Public Debt History - 21

:o Before the adjustments, the totals in Table 4 for 1871 compare with those shown for $1866-93$ as follows.

$\begin{array}{ccc}\text { Change in real debt (in billions) } & 1866-93 & 1871-91 \\ \text { Total } & \$-.30 & \$-.80 \\ \text { Attributed to debt repayment } & -2.35 & -2.03 \\ \text { Attributed to price changes } & +2.04 & +1.22\end{array}$

21 Five-year averages of nominal yields on U.S. government securities [data from Sylla (1975) 287] shows a virtually steady decline from the 1869-73 figure of 5.7 percent to 2.4 percent in $1888-92$. When these nominal yields are converted to real yields for 10-year periods to smooth the skittish Warren and Pearson (1933) wholesale price index, a 10.3 percent average real yield results for 1869-78 that drops to a low of 3.2 percent for 1879-88, primarily because of the inflation preceding the 1883 crisis, and finishes in 1883-1892, the last 10 years, with 5.6 percent.

Homer (1963) 282 has computed an average nominal yield for the preCivilWar decade of 4.3 percent that converts to a real yield of 2.6 percent.

22 Warren and Pearson (1932) 197.

23 Despite the fact that the price level was falling, the nominal value of pensions increased from a prewar figure of $\$ 1$ million to $\$ 28$ million in 1869 , $\$ 66$ million in 1883, and $\$ 107$ million in 1890. Historical Statistics (1957) Series Y 356. Public works increases were much smaller. Studenski and Krooss (1952) 165.

24 Adams (1887) 81.

2s Adams (1887) 274.

26 This difficult decision was undoubtedly intended to soften the New Deal

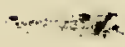


Public Debt History -22

image of business hostility. Labor experts had warned repeatedly that wage controls would never survive beyond the excess-profits tax. 
Public Debt History - 23

Table 4

Periods of U.S. Government Borrowing and Repaying

$1790-1974$

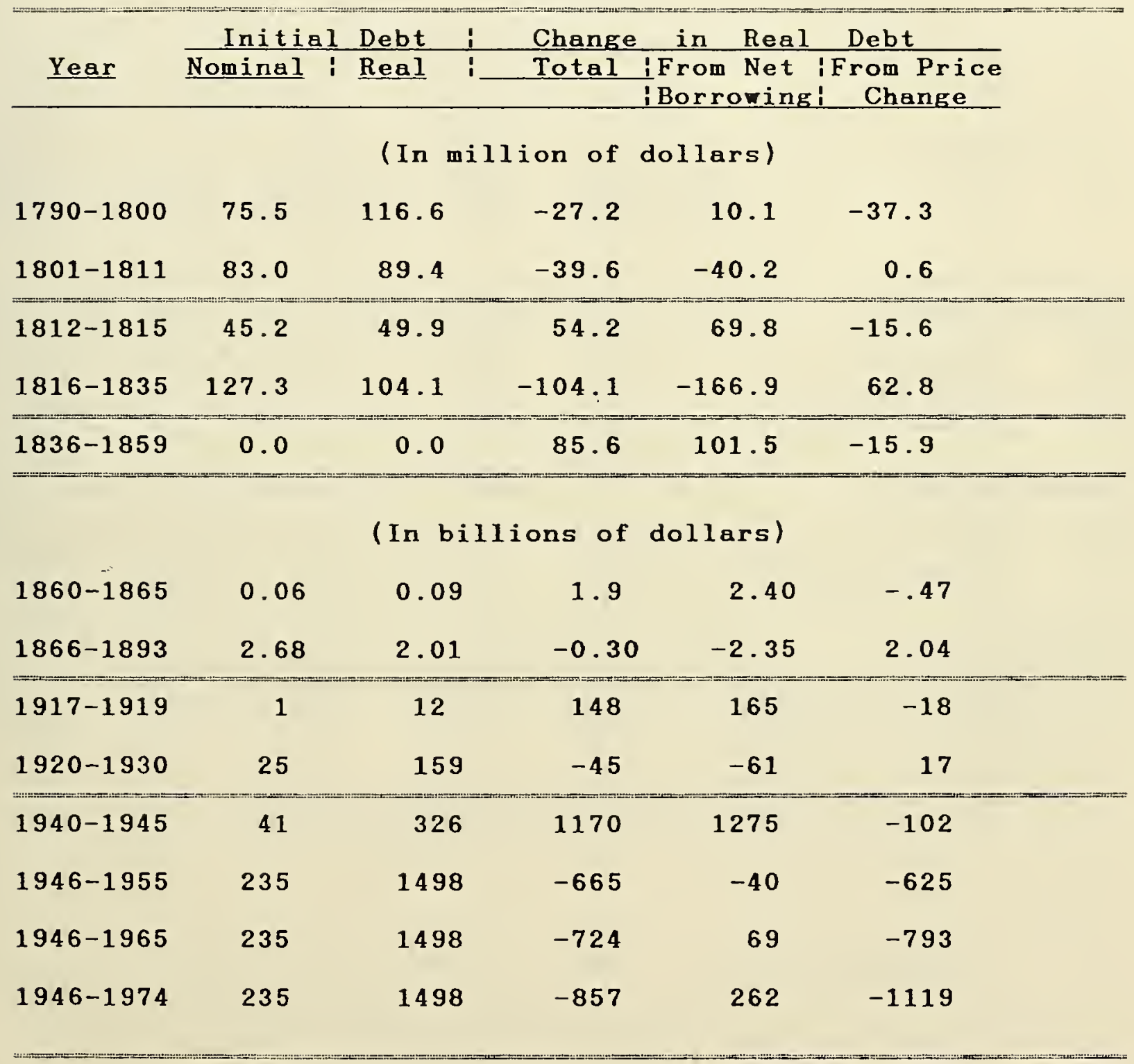

Source: Through 1930, from Table 7; from 1940, Table 8. 
Table 5

Federal Government

Average Receipts and Expenditures

$1790-1865$

$1790-1801-1812-1816-1836-1844-1850-1861-$

$\begin{array}{llllllll}1800 & 1811 & 1815 & 1835 & 1843 & 1849 & 1860 & 1865\end{array}$

\begin{tabular}{lrrrrrrrr}
\hline & & \multicolumn{1}{c}{ (In millions of dollars) } \\
Net Receipts & $\underline{6.4}$ & $\underline{13.7}$ & $\underline{12.9}$ & $\underline{26.4}$ & $\underline{25.3}$ & $\underline{31.5}$ & $\underline{56.1}$ & $\underline{178.9}+$ \\
Customs & 5.8 & 12.8 & 9.5 & 22.7 & 18.5 & 29.0 & 52.1 & 100.6 \\
Land Sales &. & 0.6 & 1.1 & 2.9 & 6.8 & 2.5 & 4.0 & 0.5 \\
Internal Taxes & 0.6 & 0.3 & 2.3 & 0.8 & 0.0 & 0.0 & 0.0 & 72.4
\end{tabular}

Expenditures

Purchases

Transfers and

Interest
6.2

9.3

3.4

5.0

28.6

19.1

33.

36.2

24 .

12.5

24.2

2.8

4.3

3. 7

6.6

9.1

5.6

6.8

61.2

Surplus

0.2

$$
\underline{7.3} \quad-8.1 \quad-4.7
$$

$\underline{3.6}=492.7$

+Customs receipts and interest payments valued at the gold premium. * Less than $0.5 \mathrm{million}$.

Source: 1790-1860: Trescott (1960) Tables 10, 11 . 1861-1865: Trescott (1966) Tables 2, 3. 
Table 6

Public Debt in the United States

Year Federal State Local ${ }^{2}$ Total $\left(\begin{array}{lllllllllll} & n & m & i & 1 & 1 & i & \circ & n & s\end{array}\right)$ $\begin{array}{cc}\text { GNP } & \text { Debt/GNP } \\ \text { Nominal } & \text { (Percent) }\end{array}$ Billions)

$\begin{array}{rrrrrrr}1825 & \$ 81 & \$ 13 & - & \$ 94 & \$ 1.0 & 10 \\ 1835 & 0 & 46 & 5 & 51 & 1.4 & 4 \\ 1840 & 5 & 176 & 20 & 201 & 1.8 & 11 \\ 1843 & 33 & 232 & 28 & 293 & 2.0 & 15 \\ 1850 & 63 & 190 & 40 & 293 & 2.5 & 12 \\ 1860 & 65 & 257 & 200 & 522 & 4.5 & 12\end{array}$

(In billions)

\begin{tabular}{rrrrrrr}
1860 & 0.1 & 0.3 & 0.2 & 0.5 & 4.5 & 12 \\
1870 & 2.4 & 0.4 & 0.5 & 3.3 & 6.7 & 49 \\
1880 & 2.1 & 0.3 & 0.8 & 3.2 & 9.2 & 35 \\
1890 & 1.1 & 0.2 & 0.9 & 2.2 & 13.1 & 17 \\
1902 & 1.2 & 0.2 & 1.6 & 3.0 & 20.3 & 15 \\
1913 & 1.2 & 0.4 & 4.0 & 5.6 & 39.9 & 14 \\
1922 & 23.0 & 1.1 & 9.0 & 33.1 & 74.8 & 44 \\
1927 & 18.5 & 2.0 & 12.9 & 33.4 & 95.8 & 35 \\
1932 & 19.5 & 2.8 & 16.4 & 38.7 & 58.5 & 66 \\
1940 & 42.8 & 3.6 & 16.7 & 63.1 & 100.4 & 63 \\
1950 & 219.0 & 5.3 & 18.8 & 243.1 & 288.3 & 84 \\
1960 & 237.2 & 18.5 & 51.4 & 307.1 & 515.3 & 60 \\
1970 & 284.9 & 42.0 & 101.6 & 428.5 & 1015.5 & 42 \\
1980 & 715.1 & 122.0 & 213.6 & 1050.7 & 2732.0 & 38 \\
1985 & 1509.9 & 211.9 & 346.6 & 2078.4 & 3998.1 & 52 \\
\hline
\end{tabular}

${ }^{1}$ Table 7.

To 1902, Hempel (1971) Table 6: 1902-70. Historical Statistics of U.S. (1970) Series Y747 and Y794; 1980-85, Statistical Abstract of U.S. To 1860. Trescott (1960) Table 14 with this writer's linear interpolations for the years 1825, 1835, and 1843; 1870-1909. Historical Statistics of the U.S.. Series F1; 1909 to present. Table 8 . 
Public Debt History - 26

\begin{tabular}{|c|c|c|c|c|c|c|c|}
\hline \multicolumn{3}{|c|}{ Nominal } & \multicolumn{4}{|c|}{$\begin{array}{l}\text { U.S. Government Debt } \\
1790-1909\end{array}$} & \multirow[b]{2}{*}{ Debt } \\
\hline \multirow[t]{2}{*}{ Year } & \multirow{2}{*}{$\begin{array}{l}\text { Price } \\
\text { Index }\end{array}$} & \multirow{2}{*}{$\begin{array}{l}\text { Price } \\
\text { Change }\end{array}$} & \multirow{2}{*}{$\mid \begin{array}{r}\text { Nominal } \\
\text { Gross } \\
\text { Debt }\end{array}$} & \multirow{2}{*}{$\begin{array}{r}\text { Real } \\
\text { Debt } \\
(1929)\end{array}$} & \multirow{2}{*}{ Change } & In Real & \\
\hline & & & & & & $\begin{array}{l}\text { From Net } \\
\text { Borrowing }\end{array}$ & $\begin{array}{c}\text { From Price } \\
\text { Change }\end{array}$ \\
\hline$(1)$ & (2) & (3) & $\begin{array}{c}\text { (4) } \\
\text { (Money } \mathrm{Fi}\end{array}$ & $\begin{array}{l}\text { (5) } \\
\text { res in }\end{array}$ & $\begin{array}{c}(6) \\
\text { Millions) }\end{array}$ & $(7)$ & $(8)$ \\
\hline 1790 & 65 & & $\$ 75.5$ & $\$ 116.6$ & & & \\
\hline 1791 & 61 & -6 & 77.2 & 126.2 & $\$ 9.6$ & $\$ 2.8$ & $\$ 6.9$ \\
\hline 1792 & $\mathrm{n} / \mathrm{a}$ & $\mathrm{n} / \mathrm{a}$ & 80.4 & $\mathrm{n} / \mathrm{a}$ & $n / a$ & $n / a$ & $\mathrm{n} / \mathrm{a}$ \\
\hline 1793 & 73 & 20 & 78.4 & 106.8 & -19.4 & 1.6 & -21.0 \\
\hline 1794 & 78 & 6 & 80.7 & 103.9 & -3.0 & 3.0 & -5.9 \\
\hline 1795 & 94 & 21 & 83.8 & 88.9 & -14.9 & 3.3 & $-18 \cdot 2$ \\
\hline 1796 & 105 & 11 & 82.1 & 78.2 & -10.8 & -1.6 & -9.1 \\
\hline 1797 & 94 & -10 & 79.2 & 84.0 & 5.9 & -3.1 & 9.0 \\
\hline 1798 & 88 & -7 & 78.4 & 89.3 & 5.3 & -0.9 & 6.2 \\
\hline 1799. & 91 & 3 & 83.0 & 91.6 & 2.2 & 5.1 & -2.8 \\
\hline 1800 & 93 & 2 & 83.0 & 89.4 & -2.1 & 0.0 & -2.1 \\
\hline $1801-$ & 102 & 10 & 80.7 & 79.0 & -10.4 & -2.3 & -8.2 \\
\hline 1802 & 84 & -18 & 77.1 & 91.6 & 12.6 & $-4 \cdot 3$ & 16.9 \\
\hline 1803 & 85 & 1 & 86.4 & 101.8 & 10.2 & 11.0 & -0.8 \\
\hline 1804 & 91 & 7 & 82.3 & 90.8 & -11.0 & -4.5 & -6.5 \\
\hline 1805 & 101 & 12 & 75.7 & 74.6 & -16.2 & -6.5 & -9.7 \\
\hline 1806 & 96 & -5 & 69.2 & 71.8 & -2.8 & -6.7 & 3.9 \\
\hline 1807 & 94 & -3 & 65.2 & 69.7 & -2.1 & -4.3 & 2.2 \\
\hline 1808 & 83 & -12 & 57.0 & 68.9 & -0.8 & -9.9 & 9.1 \\
\hline 1809 & 94 & 13 & 53.2 & 56.9 & -12.0 & $-4 \cdot 1$ & -7.9 \\
\hline 1810 & 94 & 1 & 48.0 & 50.9 & -6.0 & -5.5 & -0.4 \\
\hline 1811 & 91 & -4 & 45.2 & 49.9 & -1.1 & -3.1 & 2.0 \\
\hline 1812 & 94 & 4 & 56.0 & 59.4 & 9.6 & 11.5 & -1.9 \\
\hline 1813 & 117 & 24 & 81.5 & 69.9 & 10.5 & 21.9 & -11.4 \\
\hline 1814 & 131 & 12 & 99.8 & 76.2 & 6.3 & 14.0 & -7.7 \\
\hline 1815 & 122 & -7 & 127.3 & 104.1 & 27.9 & 22.5 & 5.4 \\
\hline 1816 & 109 & -11 & 123.5 & 113.7 & 9.6 & -3.5 & 13.1 \\
\hline 1817 & 109 & 0 & 103.5 & 95.3 & -18.4 & -18.4 & 0.0 \\
\hline 1818 & 106 & -3 & 95.5 & 90.3 & -5.0 & -7.6 & 2.6 \\
\hline 1819 & 90 & -15 & 91.0 & 101.2 & 10.9 & -5.0 & 15.9 \\
\hline 1820 & 76 & -15 & 90.0 & 118.0 & 16.8 & -1.3 & 18.1 \\
\hline 1821 & 73 & -4 & 93.5 & 127.4 & 9.4 & 4.8 & 4.6 \\
\hline 1822 & 76 & 4 & 90.9 & 119.2 & -8.2 & -3.4 & -4.8 \\
\hline 1823 & 74 & -3 & 90.3 & 121.9 & 2.7 & -0.8 & 3.5 \\
\hline 1824 & 71 & -5 & 83.8 & 118.9 & -3.0 & -9.2 & 6.2 \\
\hline
\end{tabular}


Nominal and Real U.S. Government Debt $1790-1909$

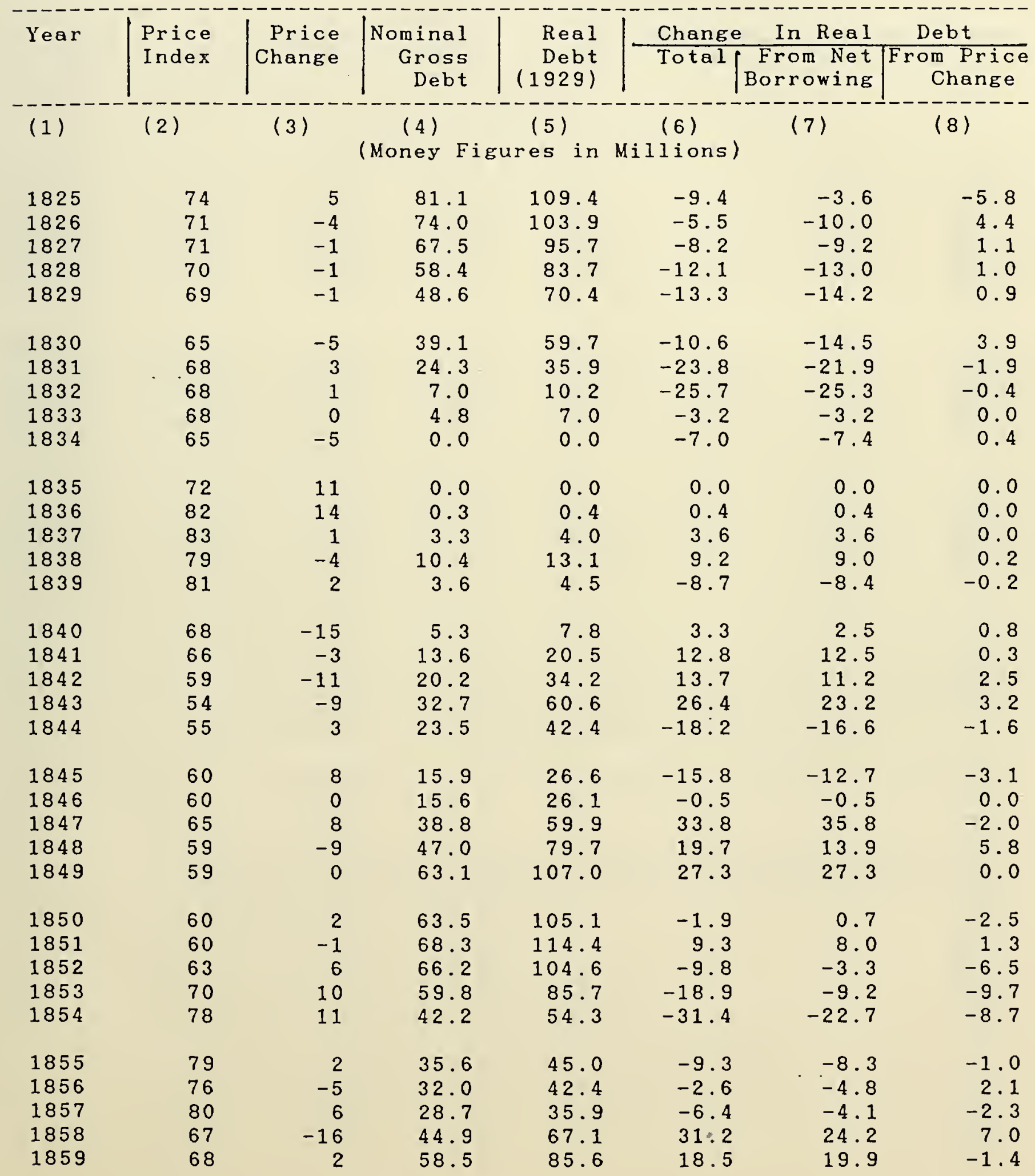


Public Debt History - 28

Table 7 (cont)

Nominal and Real U.S. Government Debt $1790-1909$

\begin{tabular}{|c|c|c|c|c|c|c|c|}
\hline Year & Price & Price & Nominal & Real & Change & In Real & Debt \\
\hline & Index & Change & $\begin{array}{r}\text { Gross } \\
\text { Debt }\end{array}$ & $\begin{array}{r}\text { Debt } \\
(1929)\end{array}$ & Total & $\begin{array}{c}\text { From Net } \\
\text { Borrowing }\end{array}$ & $\begin{array}{c}\text { From Price } \\
\text { Change }\end{array}$ \\
\hline (1) & (2) & (3) & $\begin{array}{c}\text { (4) } \\
\text { (Money Fi }\end{array}$ & $\begin{array}{l}(5) \\
\text { ures in }\end{array}$ & $\begin{array}{c}(6) \\
\text { Millions) }\end{array}$ & (7) & (8) \\
\hline 1860 & 67 & -2 & 0.06 & 0.09 & 0.00 & 0.00 & 0.00 \\
\hline 1861 & 64 & -4 & 0.09 & 0.14 & 0.05 & 0.05 & 0.00 \\
\hline 1862 & 75 & 17 & 0.52 & 0.70 & 0.55 & 0.57 & -0.02 \\
\hline 1863 & 96 & 28 & 1.12 & 1.17 & 0.48 & 0.63 & -0.15 \\
\hline 1864 & 139 & 45 & 1.82 & 1.31 & 0.14 & 0.50 & -0.36 \\
\hline 1865 & 133 & -4 & 2.68 & 2.01 & 0.70 & 0.65 & 0.06 \\
\hline 1866 & 125 & -6 & 2.76 & 2.20 & 0.19 & 0.06 & 0.13 \\
\hline 1867 & 117 & -7 & 2.65 & 2.27 & 0.07 & -0.09 & 0.16 \\
\hline 1868 & 114 & -2 & 2.58 & 2.27 & 0.00 & -0.06 & 0.06 \\
\hline 1869 & 109 & -4 & 2.55 & 2.35 & 0.08 & -0.03 & 0.11 \\
\hline 1870 & 97 & -11 & 2.44 & 2.51 & 0.16 & -0.11 & 0.28 \\
\hline 1871 & 3.4 & -4 & 2.32 & 2.48 & -0.03 & -0.13 & 0.10 \\
\hline 1872 & 98 & 5 & 2.21 & 2.26 & -0.22 & -0.11 & -0.11 \\
\hline 1873 & 96 & -2 & 2.15 & 2.25 & -0.01 & -0.06 & 0.05 \\
\hline 1874 & 91 & -5 & .2 .16 & 2.38 & 0.14 & 0.01 & 0.12 \\
\hline 1875 & 85 & -6 & 2.16 & 2.54 & 0.16 & 0.00 & 0.16 \\
\hline 1876 & 79 & -7 & 2.13 & 2.69 & 0.15 & -0.04 & 0.19 \\
\hline 1877 & 76 & -4 & 2.11 & 2.77 & 0.08 & -0.03 & 0.10 \\
\hline 1878 & 65 & -14 & 2.16 & 3.30 & 0.53 & 0.08 & 0.46 \\
\hline 1879 & 65 & -1 & 2.30 & 3.55 & 0.25 & 0.22 & 0.04 \\
\hline 1880 & 72 & 11 & 2.09 & 2.91 & -0.65 & -0.29 & -0.36 \\
\hline 1881 & 74 & 3 & 2.02 & 2.73 & -0.18 & -0.09 & -0.08 \\
\hline 1882 & 78 & 5 & 1.86 & 2.39 & -0.33 & -0.21 & -0.13 \\
\hline 1883 & 73 & -6 & 1.72 & 2.37 & -0.03 & -0.19 & 0.17 \\
\hline 1884 & 67 & -8 & 1.63 & 2.44 & 0.07 & -0.13 & 0.20 \\
\hline 1885 & 61 & -9 & 1.58 & 2.58 & 0.15 & -0.08 & 0.23 \\
\hline 1886 & 59 & -4 & 1.56 & 2.64 & 0.06 & -0.03 & 0.09 \\
\hline 1887 & 61 & 4 & 1.47 & 2.40 & -0.24 & -0.15 & -0.09 \\
\hline 1888 & 62 & 1 & 1.38 & 2.23 & -0.17 & -0.15 & -0.03 \\
\hline 1889 & 58 & -6 & 1.25 & 2.15 & -0.09 & -0.22 & 0.14 \\
\hline 1890 & 59 & 1 & 1.12 & 1.90 & -0.25 & -0.22 & -0.03 \\
\hline 1891 & 59 & 0 & 1.01 & 1.71 & -0.19 & -0.19 & 0.00 \\
\hline 1892 & 55 & -7 & 0.97 & 1.77 & 0.06 & -0.07 & 0.14 \\
\hline 1893 & 56 & 3 & 0.96 & 1.71 & -0.06 & -0.02 & -0.05 \\
\hline & & -10 & 1.02 & 2.03 & 0.31 & 0.12 & 0.20 \\
\hline
\end{tabular}




\begin{tabular}{|c|c|c|c|c|c|c|c|}
\hline \multirow[b]{2}{*}{ Year } & \multicolumn{7}{|c|}{$\begin{array}{c}\text { Nominal and Real U.S. Government Debt } \\
1790-1909\end{array}$} \\
\hline & $\begin{array}{l}\text { Price } \\
\text { Index }\end{array}$ & $\begin{array}{r}\text { Price } \\
\text { Change }\end{array}$ & $\begin{array}{r}\text { Nominal } \\
\text { Gross } \\
\text { Debt }\end{array}$ & $\begin{array}{r}\text { Real } \\
\text { Debt } \\
(1929)\end{array}$ & $\frac{\text { Change }}{\text { Total }}$ & $\left|\begin{array}{c}\text { In Real } \\
\text { Brom Net } \\
\text { Bowing }\end{array}\right|$ & 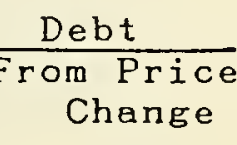 \\
\hline (1) & (2) & (3) & $\begin{array}{c}(4) \\
(\text { Money } \mathrm{Fi}\end{array}$ & $\begin{array}{c}(5) \\
\text { ures in }\end{array}$ & $\begin{array}{c}(6) \\
\text { Millions) }\end{array}$ & (7) & (8) \\
\hline $\begin{array}{l}1895 \\
1896 \\
1897 \\
1898 \\
1899\end{array}$ & $\begin{array}{l}51 \\
49 \\
49 \\
51 \\
55\end{array}$ & $\begin{array}{r}1 \\
-4 \\
0 \\
4 \\
8\end{array}$ & $\begin{array}{l}1.10 \\
1.22 \\
1.23 \\
1.23 \\
1.44\end{array}$ & $\begin{array}{l}2.15 \\
2.49 \\
2.51 \\
2.41 \\
2.60\end{array}$ & $\begin{array}{r}0.13 \\
0.34 \\
0.02 \\
-0.11 \\
0.19\end{array}$ & $\begin{array}{l}0.16 \\
0.25 \\
0.02 \\
0.00 \\
0.38\end{array}$ & $\begin{array}{r}-0.03 \\
0.10 \\
0.00 \\
-0.11 \\
-0.19\end{array}$ \\
\hline $\begin{array}{l}1900 \\
1901 \\
1902 \\
1903 \\
1904\end{array}$ & $\begin{array}{l}59 \\
58 \\
62 \\
63 \\
63\end{array}$ & $\begin{array}{r}6 \\
-1 \\
6 \\
1 \\
0\end{array}$ & $\begin{array}{l}1.26 \\
1.22 \\
1.18 \\
1.16 \\
1.14\end{array}$ & $\begin{array}{l}2.14 \\
2.09 \\
1.91 \\
1.85 \\
1.82\end{array}$ & $\begin{array}{l}-0.46 \\
-0.04 \\
-0.19 \\
-0.05 \\
-0.03\end{array}$ & $\begin{array}{l}-0.31 \\
-0.07 \\
-0.06 \\
-0.03 \\
-0.03\end{array}$ & $\begin{array}{r}-0.16 \\
0.03 \\
-0.12 \\
-0.02 \\
0.00\end{array}$ \\
\hline $\begin{array}{l}1905 \\
1906 \\
1907 \\
1908 \\
1909\end{array}$ & $\begin{array}{l}63 \\
65 \\
68 \\
66 \\
71\end{array}$ & $\begin{array}{r}1 \\
2 \\
6 \\
-3 \\
8\end{array}$ & $\begin{array}{l}1.13 \\
1.14 \\
1.15 \\
1.18 \\
1.15\end{array}$ & $\begin{array}{l}1.78 \\
1.76 \\
1.68 \\
1.78 \\
1.61\end{array}$ & $\begin{array}{r}-0.04 \\
-0.02 \\
-0.08 \\
0.10 \\
-0.17\end{array}$ & $\begin{array}{r}-0.02 \\
0.02 \\
0.01 \\
0.05 \\
-0.04\end{array}$ & $\begin{array}{r}-0.02 \\
-0.04 \\
-0.09 \\
0.05 \\
-0.13\end{array}$ \\
\hline
\end{tabular}

Sources: (2) Wholesale price index for calendar years, Warren and Pearson (1933) Table 1, pp. 10-14, adjusted to percent of 1929. The year 1792 is missing, hence the subsequent computations combine 1792-93.

(3) Percentage change in price from previous year. For year $t=$ $\left(P_{t}-P_{t-1}\right) / P_{t-1}$.

(4) Historical Statistics of the U.S. (1957) Series 257. End of calendar year through 1842; end of fiscal year, June 30, from 1843. In Series 368 the same source reports the same data but from 1791 through 1842 the previous year is shown.

(5) Column (4)/Column (2).

(6) First difference of Column (5).

(7) [First difference of Column (4)\}/Column (2).

(8) Column (6) - Column (7) $=D_{t-1}\left(P_{t-1}-P_{t}\right) / P_{t-1} P_{t}$. 


\begin{tabular}{|c|c|c|c|c|c|c|c|c|}
\hline \multirow[b]{2}{*}{ Year } & \multirow[b]{2}{*}{$\mid \begin{array}{l}\text { Price } \\
\text { Index } \\
(1982)\end{array}$} & \multirow[b]{2}{*}{$\begin{array}{c}\text { Gross } \\
\text { Debt }\end{array}$} & U.S & \multicolumn{4}{|c|}{$\begin{array}{l}\text { Table } 8 \\
\text { rernment Debt and GNP } \\
1910-1986\end{array}$} & \multirow[b]{2}{*}{$\frac{\text { Debt }}{\underset{\substack{\text { Change } \\
\text { Change }}}{\text { Prom }}}$} \\
\hline & & & GNP & $\mid \begin{array}{r}\text { Debt/ } \\
\text { GNP } \\
\text { Ratio }\end{array}$ & $\left|\begin{array}{c}\text { Rea } 1 \\
\text { Debt } \\
1982\end{array}\right|$ & $\mid \frac{\text { Change }}{\text { Total }}$ & 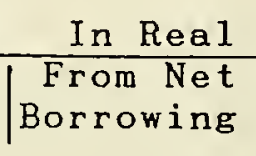 & \\
\hline (1) & (2) & (3) & $\begin{array}{c}(4) \\
\text { (Money }\end{array}$ & $\begin{array}{c}(5) \\
\text { Eigures }\end{array}$ & $\begin{array}{c}(6) \\
\text { in } \mathrm{Bi} 11\end{array}$ & $\begin{array}{r}(7) \\
\text { ions })\end{array}$ & (8) & (9) \\
\hline 1909 & 8.2 & 1 & 34 & 0.03 & 14 & & & \\
\hline 1910 & 8.4 & 1 & 36 & 0.03 & 14 & 0 & 0 & 0 \\
\hline 1911 & 8.3 & 1 & 36 & 0.03 & 14 & 0 & 0 & 0 \\
\hline 1912 & 8.7 & 1 & 40 & 0.03 & 14 & 0 & 0 & -1 \\
\hline 1913 & 8.6 & 1 & 40 & 0.03 & 14 & 0 & 0 & 0 \\
\hline 1914 & 8.8 & 1 & 39 & 0.03 & 14 & 0 & 0 & 0 \\
\hline 1915 & 9.2 & 1 & 40 & 0.03 & 13 & -1 & 0 & -1 \\
\hline 1916 & 10.3 & 1 & 49 & 0.03 & 12 & -1 & 0 & -1 \\
\hline 1917 & 12.6 & 3 & 61 & 0.05 & 24 & 12 & 14 & -2 \\
\hline 1918 & 13.5 & 12 & 77 & 0.16 & 92 & 69 & 70 & -2 \\
\hline 1919 & 16.0 & 25 & 85 & 0.30 & 159 & 67 & 81 & -14 \\
\hline 1920 & 18.9 & 24 & 92 & 0.26 & 129 & -31 & -6 & -24 \\
\hline 1921 & 15.5 & 24 & 70 & 0.34 & 155 & 26 & -2 & 28 \\
\hline 1922 & 14.4 & 23 & 75 & 0.31 & 159 & 5 & -7 & 12 \\
\hline 1923 & 14.9 & 22 & 86 & 0.26 & 150 & -9 & -4 & -5 \\
\hline 1924 & 14.7 & 21 & 86 & 0.25 & 145 & -5 & -7 & 2 \\
\hline 1925 & 15.0 & 21 & 94 & 0.22 & 137 & -8 & -5 & -3 \\
\hline 1926 & 14.8 & 20 & 98 & 0.20 & 133 & -4 & -6 & 2 \\
\hline 1927 & 14.5 & 19 & 96 & 0.19 & 128 & -5 & -8 & 3 \\
\hline 1928 & 14.6 & 18 & 98 & 0.18 & 121 & -7 & -6 & -1 \\
\hline 1929 & 14.6 & 17 & 104 & 0.16 & 116 & -5 & -5 & 0 \\
\hline 1930 & 14.2 & 16 & 91 & 0.18 & 114 & -2 & -5 & 3 \\
\hline 1931 & 13.0 & 17 & 76 & 0.22 & 129 & 15 & 5 & 11 \\
\hline 1932 & 11.5 & 20 & 59 & 0.33 & 170 & 40 & 23 & 17 \\
\hline 1933 & 11.2 & 23 & 56 & 0.40 & 201 & 31 & 27 & 5 \\
\hline 1934 & 12.2 & 27 & 66 & 0.41 & 222 & 21 & 38 & -16 \\
\hline 1935 & 12.5 & 29 & 73 & 0.39 & 230 & 7 & 13 & -5 \\
\hline 1936 & 12.5 & 34 & 83 & 0.41 & 270 & 41 & 41 & 0 \\
\hline 1937 & 13.1 & 36 & 91 & 0.40 & 278 & 7 & 20 & -12 \\
\hline 1938 & 12.9 & 37 & 85 & 0.44 & 288 & 11 & 6 & 4 \\
\hline 1939 & 12.7 & 41 & 91 & 0.45 & 326 & 38 & 33 & 5 \\
\hline 1940 & 13.0 & 43 & 100 & 0.43 & 329 & 3 & 11 & -8 \\
\hline 1941 & 13.8 & 48 & 126 & 0.39 & 351 & 21 & 41 & -19 \\
\hline 1942 & 14.7 & 68 & 159 & 0.43 & 461 & 110 & 132 & -21 \\
\hline 1943 & 15.1 & 128 & 193 & 0.66 & 846 & 385 & 397 & -12 \\
\hline 1944 & 15.3 & 185 & 211 & 0.87 & 1208 & 361 & 373 & -11 \\
\hline
\end{tabular}




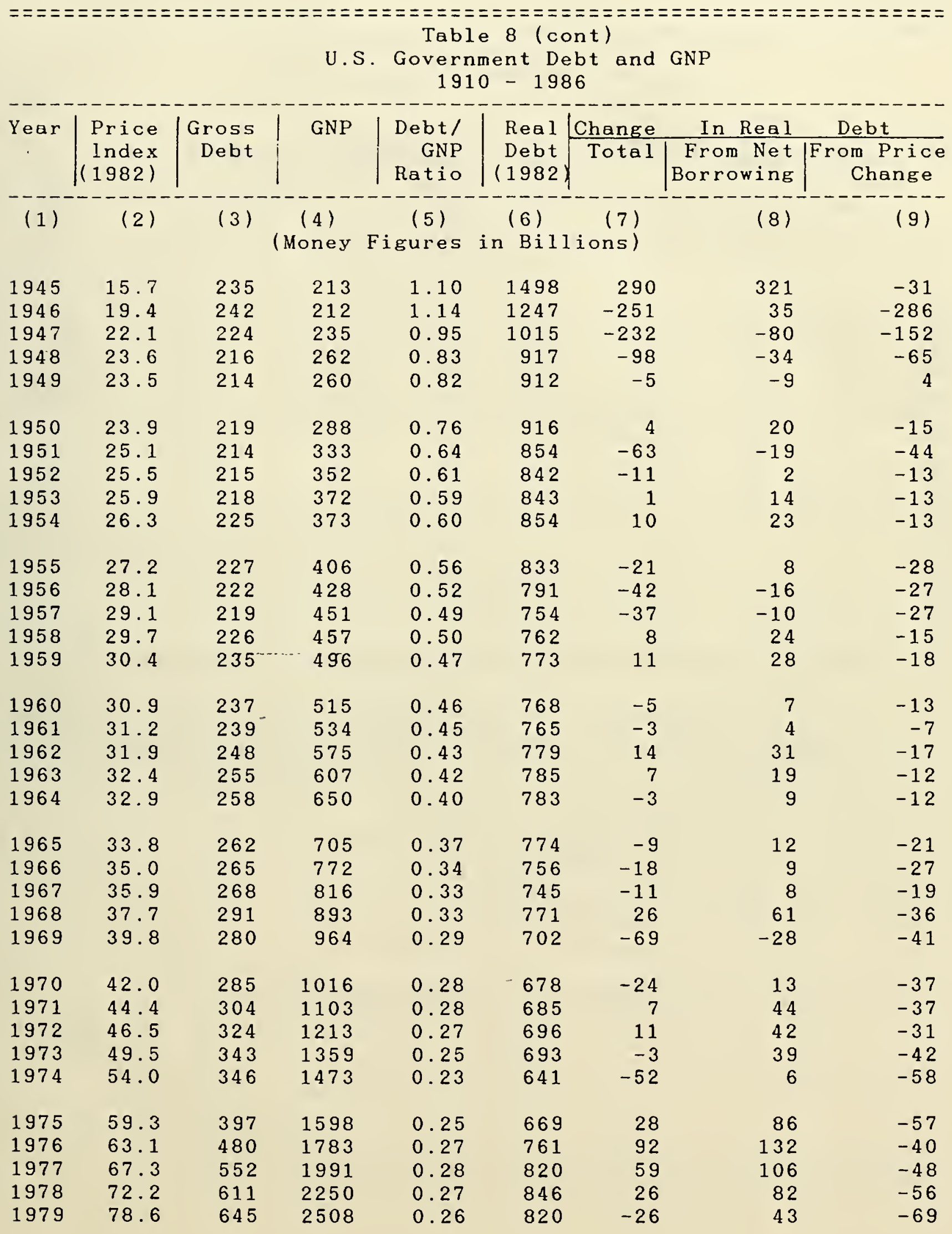




\begin{tabular}{|c|c|c|c|c|c|c|c|c|}
\hline \multirow[b]{2}{*}{ Year } & \multirow[b]{2}{*}{$\begin{array}{l}\text { Price } \\
\text { Index } \\
(1982)\end{array}$} & \multirow[b]{2}{*}{$\begin{array}{r}\text { Gross } \\
\text { Debt }\end{array}$} & U.s & \multicolumn{4}{|c|}{$\begin{array}{c}\text { Government Debt and GNP } \\
1910-1986\end{array}$} & \multirow[b]{2}{*}{$\frac{\text { Debt }}{\left[\begin{array}{c}\text { From Price } \\
\text { Change }\end{array}\right.}$} \\
\hline & & & GNP & $\begin{array}{r}\text { Debt/ } \\
\text { GNP } \\
\text { Ratio }\end{array}$ & $\begin{array}{r}\text { Real } \\
\text { Debt } \\
1982\end{array}$ & $\frac{\text { Change }}{\text { Total }}$ & 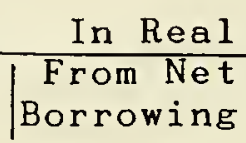 & \\
\hline (1) & $(2)$ & (3) & $\begin{array}{c}(4) \\
\text { (Money }\end{array}$ & $\begin{array}{c}(5) \\
\text { Figures }\end{array}$ & $\begin{array}{c}(6) \\
\text { in } B i 11\end{array}$ & $\begin{array}{r}(7) \\
\text { ions })\end{array}$ & (8) & (9) \\
\hline 1980 & 85.7 & 715 & 2732 & 0.26 & 834 & 14 & 82 & -68 \\
\hline 1981 & 94.0 & 794 & 3053 & 0.26 & 845 & 11 & 84 & -74 \\
\hline 1982 & 100.0 & 929 & 3166 & 0.29 & 929 & 84 & 135 & -51 \\
\hline 1983 & 103.9 & 1142 & 3406 & 0.34 & 1099 & 170 & 204 & -35 \\
\hline 1984 & 107.7 & 1313 & 3772 & 0.35 & 1219 & 120 & 159 & -39 \\
\hline 1985 & 111.2 & 1510 & 4010 & 0.38 & 1358 & 139 & 177 & -38 \\
\hline 1986 & 114.1 & 1746 & 4235 & 0.41 & 1530 & 173 & 207 & -35 \\
\hline
\end{tabular}

Sources: (2) Implicit GND price index as percent of 1982 base, U.S. Commerce (1986, 1987).

(3) Through 1939, Historical Statistics of the U.S. (1957) Series 257; 1940 to present, debt in hands of public. Economic Report of the President. 1987), end of fiscal year: June 30, through 1976; September 30, 1977 to present.
(4) U.S. Commerce $(1986,1987)$.
(5) Column (3)/Column (4).
(6) Column (3)/Column (2).
(7) First difference of Column (6).
(8) \{First difference of Column (3)\}/Column (2).
(9) Column (7) - Column (8) $=D_{t-1}\left(P_{t-1}-P_{t}\right) / P_{t-1} P_{t}$. 


\section{References}

Adams, Henry C., Public Debts (New York: D. Appleton and Company, 1887). Alesina, Alberto, "The end of large public debts?" in Francesco Giavazzi and Luigi Spaventa, Eds., High Public Debt: The Italian Experience (Cambridge: Cambridge University Press, 1988) 34-79.

Barro, Robert J., Macroeconomics (New York: John Wiley \& Sons, Inc., 1984).

-----"U.S. Deficits Since World War I," Scandinavian Journal of Economics, $88(1,1986) 195-222$.

--- "The Ricardian Approach to Budget Deficits," The Journal of Economic Perspectives (3 (Spring 1989) 37-54.

Childs, C. F., Concerning U.S. Government Securities (Chicago: C.F. Childs and Company, 1947).

Dewey; Davis-R., Financiat History of the United States, 12th ed. (New York: Longman's Green and Co., 1934).

Friedman, Milton and Anna Jacobson Schwartz, A Monetary History of the United States, 1867-1960 (Princeton: Princeton University Press).

Hempel, George H., Postwar Quality of State and Local Debt (New York: National Bureau of Economic Research, 1971).

Homer, Sidney, A History of Interest Rates (New Brunswick, N.J.: Rutgers University Press, 1963).

Paul, Randolph E., Taxation in the United States (Boston: Little, Brown \& Co., 1954).

Ratchford, B. U., American State Debts (Durham, North Carolina: Duke University Press, 1941).

Ratner, Sidney, James H. Soltow, and Richard Sylla, The Evolution of the 
American Economy (New York: Basic Books, Inc., 1979).

Studenski, Paul and Herman E. Krooss, Financial History of the United

States (New York: McGraw-Hill Book Company. Inc., 1952).

Sylla, Richard, The American Capital Market, 1846-1914 (New York: Arno Press, 1975).

Temin. Peter. The Jacksonian Economy (New York: W. W. Norton \& Company, Inc., 1969).

Trescott, Paul B., "Federal-State Financial Relations, 1790-1860", The Journal of Economic History 15 (September 1955) 227-245.

----"Some Historical Aspects of Federal Fiscal Policy, 1790-1956," in U.S. Joint Economic Committee. Federal Expenditure Policy for Economic Growth and Development (Washington: Government Printing Office, 1957) 60-83.

-- "The United States Government and National Income, 1790-1860" in Trends in the American Economy in the Nineteenth Century (Princeton: Princeton University Press, 1960) 337-361.

- "Federal Government Receipts and Expenditures, 1861-1875," The Journal of Economic History 26(June 1966) 206-222.

U.S. Department of Commerce, Historical Statistics of the United States (1957) and (1970) (Washington: Government Printing Office, 1960 and 1976).

----The National Income and Product Accounts of the United States, 192982 (Washington: Government Printing Office, 1986).

---- National Income and Product Accounts," Survey of Current Business 67 (July 1987).

Warren, George F. and Frank A. Pearson, Prices (New York: John Wiley \& Sons, Inc., 1933). 



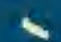





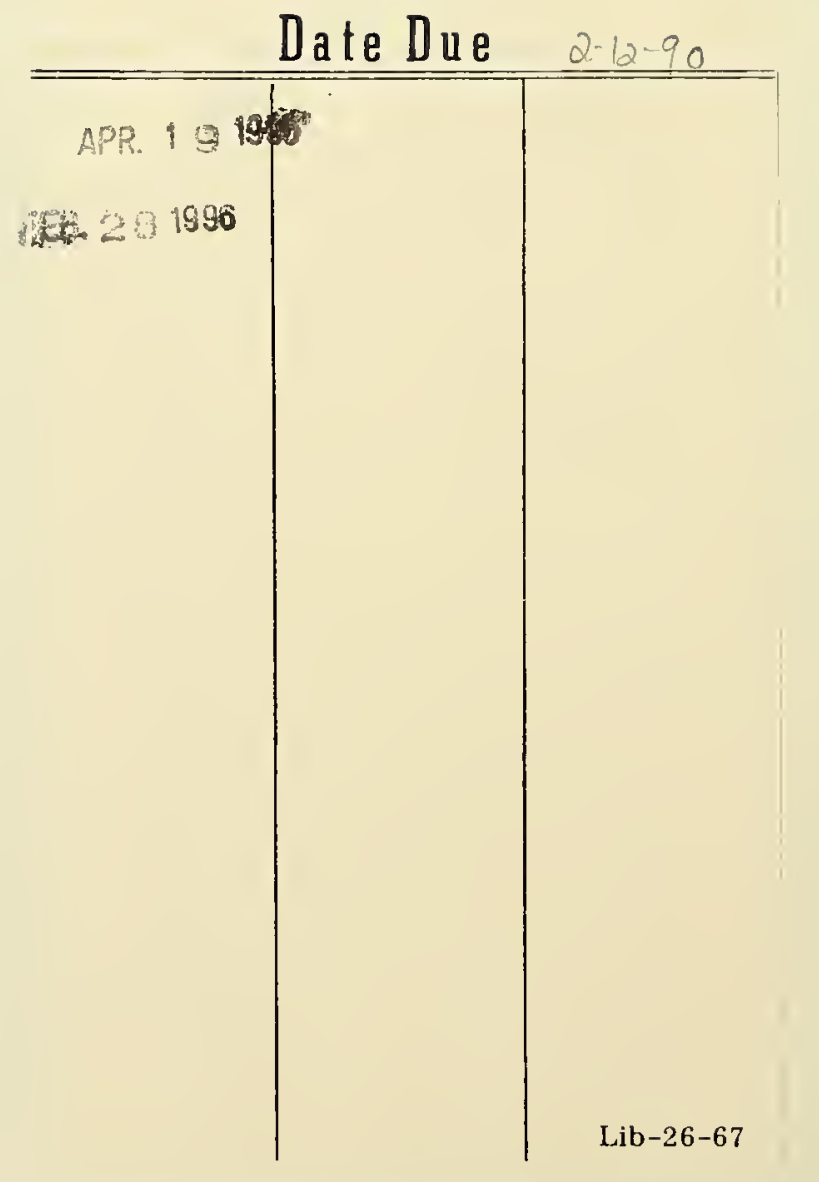




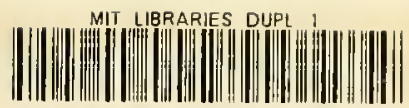

3908000578964 b 
